\title{
PHYSICO-CHEMICAL PROPERTIES OF BRICK KILN DUST AMENDED SOILS AND THEIR EFFECT ON SOLANUM TUBEROSUM
}

\author{
Deepali Tomar and Abrar A. Khan \\ Department of Botany \\ Aligarh Muslim University, Aligarh-202 002, India \\ E-mail: abraramu@rediffmail.com, deepalitomar@yahoo.com
}

\begin{abstract}
The study was conducted to analyze the physico-chemical properties of various levels of brick kiln dust in soil application $(0,5,10,15,20,25,30,40$ and 50\%), before planting and after harvesting of potato (Solanum tuberosum) crop and to observe their impact on various parameters of potato plant. The $\mathrm{pH}, \mathrm{EC}, \mathrm{CEC}$, WHC, pore space, sulphate, chloride, phosphorus, magnesium, zinc, manganese and boron increased at all the levels of brick kiln dust, while, nitrogen and potassium decreased at all the levels before planting of potato crop. After harvesting of potato crop all physico-chemical properties were still greater than control but less than pre-planting of potato, except $\mathrm{P}$ and $\mathrm{Mg}$ which decreased gradually upto $30 \%$; and $\mathrm{K}$ as well as Mn upto $40 \%$, and then they increased in subsequent levels. While $\mathrm{N}$ was recorded only in control and at $50 \%$ treatment. Application of brick kiln dust in soil from $5 \%$ to $40 \%$ was found beneficial for plant growth, yield, biomass, photosynthetic pigments, carbohydrate contents, and phosphorus and potassium concentrations of plants and the highest increase in above parameters was recorded at $25 \%$ level. At $50 \%$ level, there was marked reduction in all these parameters. However, nitrogen concentration of plants and protein content in tubers decreased gradually as levels of kiln dust were increased.
\end{abstract}

Key words: Amendment, brick kiln dust, potato.

\section{INTRODUCTION}

In India, particulate air pollutants viz. fly ash, cement dust, brick kiln dust, coal dust, soil dust and textile dust are major problem. These particulate materials are the result of uncontrolled mechanization of industries. Brick is a common construction material widely used all over the country. Generally, brick making industries are established near the agricultural lands in rural areas. For firing the bricks, wood and coal are used as fuel. Large number of brick industries are running throughout the country. In Aligarh district, about 250 brick kilns are in operation. In one round, about 6,00,000 bricks are prepared. The consumption of coal and wood is about 12-18 $\mathrm{t}$ for preparing 100,000 bricks (Upadhyay 2004). Complete combustion of fuel in brick kilns leads to the formation of fluoride, carbon dioxide, water molecules, oxides of nitrogen, sulphur dioxide, sulphur trioxide and large amount of brick kiln dust.

Particulates as brick kiln dust are dumped in pits or kept as stock piles. Particulate pollutants after moving far away from their source of origin 
fall and get deposited on the plant parts and soil surface. After settling and mixing with soil, they influence the growth and yield of crops (Heck et al. 1970). The beneficial effects of fly ash on biomass and other plant growth parameters have been noticed in onion, potato and garlic (Khan et al. 2006), soybean and maize (Mishra and Shukla, 1986), mustard (Upadhyay et al. 2008). Recently Rizvi and Khan (2009) observed improvement in plant growth and yield of eggplant when fly ash and brick kiln dust were applied to soil at $20 \%$ and $30 \%$ levels, respectively. The particulates actually change the physico-chemical properties of soil. Recently use of some particulates as a fertilizer has been advocated by some workers (Mishra and Shukla 1986, Khan 1989, Wong and Wong 1989, Khan and Singh 1996, Raghav and Khan 2002). Therefore, potato was evaluated against different levels of brick kiln dust as soil application.

\section{MATERIALS AND METHODS}

\section{Application of brick kiln dust with soil}

For the experiment, brick kiln dust was obtained from the brick kiln situated at Manzoor Garhi, Aligarh. Soil was collected from agricultural fields up to $20 \mathrm{~cm}$ depth after scrapping of the surface litters present, if any. The soil was sandy loam. It was autoclaved before incorporation.

The brick kiln dust was mixed with soil in the following proportions.

$$
\begin{aligned}
& \text { Control }=0 \mathrm{~g} \text { brick kiln dust }+3000 \mathrm{~g} \text { soil } \\
& 5 \%=150 \mathrm{~g} \text { brick kiln dust }+2850 \mathrm{~g} \text { soil } \\
& 10 \%=300 \mathrm{~g} \text { brick kiln dust }+2700 \mathrm{~g} \text { soil } \\
& 15 \%=450 \mathrm{~g} \text { brick kiln dust }+2550 \mathrm{~g} \text { soil } \\
& 20 \%=600 \mathrm{~g} \text { brick kiln dust }+2400 \mathrm{~g} \text { soil } \\
& 25 \%=750 \mathrm{~g} \text { brick kiln dust }+2250 \mathrm{~g} \text { soil } \\
& 30 \%=900 \mathrm{~g} \text { brick kiln dust }+2100 \mathrm{~g} \text { soil } \\
& 40 \%=1200 \mathrm{~g} \text { brick kiln dust }+1800 \mathrm{~g} \text { soil } \\
& 50 \%=1500 \mathrm{~g} \text { brick kiln dust }+1500 \mathrm{~g} \text { soil }
\end{aligned}
$$

After proper mixing, clay pots of $30 \mathrm{~cm}$ height (25 cm diameter) closed at bottom were filled with $3 \mathrm{~kg}$ of each type of mixture. Each treatment was replicated five times. Total 45 pots including control set were prepared for the experiments (9 treatments $\times 5$ replicates). Analysis of soil from each treatment was done before planting and after harvesting of potato following the standard methods. The physico- chemical parameters: water holding capacity (WHC), pore space, sulphate, chloride, magnesium, zinc, manganese and boron were determined by the standard methods (Gupta 2002), nitrogen as described by Subbiah and Asija

\begin{tabular}{|c|c|c|c|c|}
\hline \multicolumn{2}{|c|}{ Parameter } & \multirow{2}{*}{\begin{tabular}{|l|} 
Soil \\
6.79 \\
\end{tabular}} & \multirow{2}{*}{$\begin{array}{c}\begin{array}{c}\text { Brick kiln } \\
\text { dust }\end{array} \\
9.5\end{array}$} & \multirow{2}{*}{$\begin{array}{c}\begin{array}{c}\text { Tap } \\
\text { water }\end{array} \\
7.2\end{array}$} \\
\hline $\mathrm{pH}$ & & & & \\
\hline $\begin{array}{l}\text { Electrical } \\
\text { conductivity }\end{array}$ & $\begin{array}{l}(\mathrm{mmhos} \\
\left.\mathrm{cm}^{-1}\right)\end{array}$ & 0.05 & 0.180 & \\
\hline $\begin{array}{l}\text { Cation } \\
\text { exchange } \\
\text { capacity }\end{array}$ & $\begin{array}{l}(\mathrm{mEq} / \\
100 \mathrm{~g})\end{array}$ & 3.00 & 7.10 & \\
\hline $\begin{array}{l}\text { Water holding } \\
\text { capacity }\end{array}$ & $(\%)$ & 42 & 90 & \\
\hline Pore space & $(\%)$ & 40.12 & 80.7 & \\
\hline Sulphate & $(\mathrm{mg} / \mathrm{l})$ & 15 & 27.3 & 6.0 \\
\hline Chloride & $(\mathrm{mg} / \mathrm{l})$ & 49 & 85 & 22 \\
\hline Nitrogen & $(\mathrm{mg} / \mathrm{kg})$ & 95.0 & 65.0 & \\
\hline Phosphorus & $(\mathrm{mg} / \mathrm{kg})$ & 11.5 & 18.5 & $\begin{array}{c}0.13 \\
(\mathrm{mg} / \mathrm{l})\end{array}$ \\
\hline Potassium & $(\mathrm{mg} / \mathrm{kg})$ & 51.7 & 35.4 & $\begin{array}{c}5.75 \\
(\mathrm{mg} / \mathrm{l})\end{array}$ \\
\hline Magnesium & $(\mathrm{mg} / \mathrm{kg})$ & 37.0 & 41.2 & $\begin{array}{c}5.12 \\
(\mathrm{mg} / \mathrm{l})\end{array}$ \\
\hline Zinc & $(\mathrm{mg} / \mathrm{kg})$ & 1.5 & 2.3 & \\
\hline Manganese & $(\mathrm{mg} / \mathrm{kg})$ & 5.7 & 5.9 & \\
\hline Boron & $(\mathrm{mg} / \mathrm{kg})$ & 0.47 & 1.5 & \\
\hline
\end{tabular}
(1956), phosphorus by Olsen et al. (1956) and potassium by Flame photometer; while $\mathrm{pH}$, EC (Electrical conductivity), CEC (Cation exchange capacity) by Conductivity meter. The characteristics of soil, brick kiln dust and tap water used in the experiment are given in Table 1.

Table 1. Characteristics of soil, brick kiln dust and tap water (values are mean, $n=5$ ).

ECOPRINT VOL 18, 2011 


\section{Plant culture and setting of experiment}

Potato (Solanum tuberosum L.) var. Kufri Alankar, commonly grown in India, was selected as test crop. Small square pieces (size $2.5-3.0 \mathrm{~cm}^{2}$ ) of potato tubers were cut in such a way that each piece had at least one eye. The pieces were surface sterilized (dipped in $0.01 \% \mathrm{HgCl}_{2}$ for $15 \mathrm{~min}$ ) before planting. A small pit (5 $\mathrm{cm}$ deep) was made in the centre of each pot already prepared with different concentrations of brick kiln dust amended soil. One potato piece was placed into the pit of each pot in such a way that eye was always towards upper side. Pots were arranged in randomized block design on glasshouse benches at $27 / 23^{\circ} \mathrm{C}$ day/night temperature. Photosynthetic active radiation was PAR $>750 \mu \mathrm{mol} \mathrm{m} \mathrm{m}^{-2} \mathrm{~s}^{-1}$ between 1100 and $1200 \mathrm{~h}$, and humidity in the green house was $67 \pm 5 \%$. Pots were irrigated on alternate days with limited amount (200-250 ml) of tap water just to moist the soil and surface flow was avoided. Approximately 10-12 1 of water per pot was used till the harvesting of plant. Plants were uprooted carefully after 90 days. Roots and potato tubers were thoroughly washed under tap water to avoid soil particles and debris. Plant growth and yield were determined. The photosynthetic pigments, NPK concentrations of plants, protein and carbohydrate contents of potato were estimated through standard methods presented by Mac Lachan and Zalik (1963), Gupta (2002), Lowery et al. (1951) and Yih (1965), respectively. Data were analyzed statistically for significance.

\section{RESULTS}

\section{Physico-chemical properties of amended soils before planting}

Data comprised in Table 2 show that there was a significant $(p<0.05$ and $p<0.01)$ and gradual increase in $\mathrm{pH}, \mathrm{EC}, \mathrm{CEC}, \mathrm{WHC}$ and pore space with increase in the level of brick kiln dust in soil. Five percent treatment, however, these were nonsignificant either at $\mathrm{p}<0.05$ or $\mathrm{p}<0.01$ level. Sulphate and chloride were increased significantly $(\mathrm{p}<0.05$ and $\mathrm{p}<0.01)$ with the increase in the levels, except at 5\% treatment, where these parameters were at par with control.

In NPK concentrations, $\mathrm{N}$ and $\mathrm{K}$ were decreased gradually and significantly with the increment in the levels, except at 5\% level of brick kiln dust, where $\mathrm{K}$ was non-significant. However, $\mathrm{P}$ increased significantly as compared to control, except at 5 and $10 \%$ treatments (Table 2).

$\mathrm{Mg}, \mathrm{Zn}$ and B increased significantly $(\mathrm{p}<0.05$ and $p<0.01)$ with the increasing level of brick kiln dust, except $\mathrm{Mg}$ at $5 \%$ level and $\mathrm{Zn}$ from 5 to $15 \%$ treatments, where these parameters were similar to control. However, the increase in $\mathrm{Mn}$ was significant (Table 2).

\section{Physico-chemical properties of amended soils after harvesting}

Data summarized in Table 3 shows that there was gradual and significant increment in $\mathrm{pH}, \mathrm{EC}$, CEC, WHC and pore space with the increase in brick kiln dust level, except EC, CEC and WHC which were non-significant $(\mathrm{p}<0.01)$ at $5 \%$ treatment. This table also shows that there was gradual and significant increase in sulphate and chloride contents in all the levels except at 5\% treatment, where these were non-significant.

In NPK concentrations, $\mathrm{N}$ was recorded only in control $(1.5 \mathrm{mg} / \mathrm{kg})$ and at $50 \%$ level $(3.5$ $\mathrm{mg} / \mathrm{kg}$ ). However, $\mathrm{P}$ and $\mathrm{K}$ were first decreased significantly upto $25 \%$ level and then increased slowly in subsequent levels, except $\mathrm{K}$ at $5 \%$ treatment (Table 3).

Similarly, $\mathrm{Mg}$ and $\mathrm{Mn}$ were also decreased gradually upto $25 \%$ level then increased gradually in subsequent levels. The increase were nonsignificant at 5, 10, 30 and 40\% levels for $\mathrm{Mg}$; and at 5 and $40 \%$ for $\mathrm{Mn}$. However, $\mathrm{Zn}$ and $\mathrm{B}$ increased significantly at all the treatments when compared to control, except $\mathrm{Zn}$ which was nonsignificant at 5, 10 and $15 \%$ levels, while B at 5\% level (Table 3). 
Table 2.Physico-chemical properties of brick kiln dust amended soil before planting of S. tuberosum var. Kufri Alankar (values are mean, $n=5$ ).

\begin{tabular}{|c|c|c|c|c|c|c|c|}
\hline $\begin{array}{c}\text { Treatment } \\
(\%)\end{array}$ & pH & $\begin{array}{c}\text { Electrical } \\
\text { conductivity } \\
\left(\mathbf{m m h o s} \mathbf{c m}^{-1}\right)\end{array}$ & $\begin{array}{c}\text { Cation } \\
\text { exchange } \\
\text { capacity } \\
(\mathbf{m E q} / 100 \mathrm{~g})\end{array}$ & $\begin{array}{c}\text { Water } \\
\text { holding } \\
\text { capacity } \\
(\%)\end{array}$ & $\begin{array}{c}\text { Pore } \\
\text { space } \\
(\%)\end{array}$ & $\begin{array}{c}\text { Sulphate } \\
\text { content } \\
(\mathrm{mg} / \mathrm{l})\end{array}$ & $\begin{array}{c}\text { Chloride } \\
\text { content } \\
(\mathrm{mg} / \mathrm{l})\end{array}$ \\
\hline 0 & 6.79 & 0.050 & 3.00 & 42.00 & 40.12 & 15.0 & 49.0 \\
\hline 5 & 6.92 & 0.053 & 3.20 & 43.12 & 43.60 & 15.4 & 49.8 \\
\hline 10 & 7.11 & 0.057 & 3.46 & 47.01 & 46.12 & 16.0 & 51.3 \\
\hline 15 & 7.31 & 0.061 & 3.71 & 50.10 & 49.47 & 16.5 & 53.3 \\
\hline 20 & 7.52 & 0.065 & 3.95 & 53.21 & 52.50 & 17.2 & 55.1 \\
\hline 25 & 7.75 & 0.070 & 4.24 & 57.60 & 55.31 & 17.8 & 57.0 \\
\hline 30 & 7.96 & 0.075 & 4.50 & 60.27 & 57.73 & 18.5 & 59.1 \\
\hline 40 & 8.25 & 0.084 & 5.00 & 64.50 & 60.28 & 19.7 & 62.2 \\
\hline 50 & 8.67 & 0.095 & 5.52 & 68.25 & 63.75 & 20.8 & 65.7 \\
\hline LSD $(\mathrm{P}<0.05)$ & 0.134 & 0.003 & 0.157 & 2.349 & 2.761 & 0.35 & 0.75 \\
\hline LSD $(\mathrm{P}<0.01)$ & 0.181 & 0.005 & 0.212 & 3.167 & 3.721 & 0.47 & 1.01 \\
\hline Treatment (\%) & $\begin{array}{c}\text { Nitrogen } \\
(\mathrm{mg} / \mathrm{kg})\end{array}$ & $\begin{array}{l}\text { Phosphorus } \\
\text { (mg/kg) }\end{array}$ & $\begin{array}{c}\text { Potassium } \\
\text { (mg/kg) }\end{array}$ & $\begin{array}{c}\text { Magnesium } \\
\text { (mg/kg) }\end{array}$ & $\begin{array}{c}\text { Zinc } \\
(\mathrm{mg} / \mathrm{kg})\end{array}$ & $\begin{array}{c}\text { Manganese } \\
(\mathrm{mg} / \mathrm{kg})\end{array}$ & $\begin{array}{c}\text { Boron } \\
\text { (mg/kg) }\end{array}$ \\
\hline 0 & 95 & 11.5 & 51.7 & 37.0 & 1.50 & 5.70 & 0.47 \\
\hline 5 & 93 & 11.6 & 50.7 & 37.1 & 1.52 & 5.65 & 0.50 \\
\hline 10 & 91 & 12.0 & 50.0 & 37.3 & 1.59 & 5.67 & 0.56 \\
\hline 15 & 89 & 12.3 & 49.1 & 37.5 & 1.60 & 5.71 & 0.61 \\
\hline 20 & 88 & 12.7 & 48.3 & 37.7 & 1.65 & 5.72 & 0.65 \\
\hline 25 & 87 & 13.0 & 47.5 & 38.0 & 1.68 & 5.73 & 0.71 \\
\hline 30 & 85 & 13.4 & 46.7 & 38.1 & 1.73 & 5.74 & 0.76 \\
\hline 40 & 82 & 14.3 & 45.0 & 38.5 & 1.80 & 5.75 & 0.85 \\
\hline 50 & 79 & 15.0 & 43.4 & 39.0 & 1.91 & 5.77 & 0.96 \\
\hline LSD $(\mathrm{P}<0.05)$ & 1.4 & 0.53 & 0.97 & 0.17 & 0.075 & 0.251 & 0.021 \\
\hline LSD $(\mathrm{P}<0.01)$ & 1.9 & 0.71 & 1.31 & 0.23 & 0.101 & 0.338 & 0.028 \\
\hline
\end{tabular}

\section{Plant growth and yield}

Data presented in Table 4 reveal that potato crop showed variable growth responses to different levels of brick kiln dust in soil. At $25 \%$ level treatment, plant growth in terms of length, fresh wt and dry wt of root and shoot was much better than other levels, however, a significant increase $(\mathrm{p}<0.05$ and $\mathrm{p}<0.01)$ in growth parameters was observed from $10 \%$ to $30 \%$ levels of treatment. At $50 \%$ level, there were marked reductions in all these parameters. Highest increase in length, fresh wt and dry wt of shoot and root were recorded at $25 \%$ level.
The yield in terms of tuber fresh weight and tuber dry weight was also affected by soil application of brick kiln dust. The significant increase $(p<0.05$ and $p<0.01)$ in these parameters was observed from 10 to $30 \%$ levels. Highest increase in tuber fresh weight and tuber dry weight was recorded at $25 \%$ level. At $50 \%$ level, these parameters decreased significantly. Similar result was also observed for biomass.

\section{Photosynthetic pigments and NPK}

Table 5 shows that photosynthetic pigments of leaves gradually increased with the increase in the 
levels of treatment. Significant increase in chlorophyll a, chlorophyll b, total chlorophyll and carotenoids was recorded from 10 to $30 \%$ levels, highest being at $25 \%$ level. At $50 \%$ level, there was marked reduction in chlorophyll $b$ and total chlorophyll as compared to control.

In NPK concentrations of plants, $\mathrm{N}$ was gradually decreased $(\mathrm{p}<0.05$ and $\mathrm{p}<0.01)$ with respect to the increasing levels, however, at $5 \%$ level it was non-significant as compared to control. $\mathrm{P}$ and $\mathrm{K}$ were significantly increased $(\mathrm{p}<0.05$ and $\mathrm{p}<0.01$ ) from 10 to $30 \%$ levels, highest being at $25 \%$ level. At $50 \%$ level, these parameters were significantly reduced as compared to control (Table 5).

\section{Protein and carbohydrate}

Table 6 shows that soluble, insoluble and total protein were decreased gradually as the levels of brick kiln dust were increased. Highest reduction in these parameters was recorded in the range between 15 to $50 \%$ application. However, soluble, insoluble and total carbohydrate were increased significantly from 15 to $30 \%$ levels, highest being at $25 \%$ level. In rest of the treatments all these parameters were non-significant as compared to control.

Table 3. Physico-chemical properties of brick kiln dust amended soil after harvesting of $S$. tuberosum var. Kufri Alankar (values are mean, $\mathrm{n}=5$ ).

\begin{tabular}{|c|c|c|c|c|c|c|c|}
\hline $\begin{array}{c}\text { Treatment } \\
(\%)\end{array}$ & pH & $\begin{array}{c}\text { Electrical } \\
\text { conductivity } \\
\left(\mathbf{m m h o s} \mathbf{c m}^{-1}\right)\end{array}$ & $\begin{array}{c}\text { Cation } \\
\text { exchange } \\
\text { capacity } \\
\text { (mEq/100 g) }\end{array}$ & $\begin{array}{c}\text { Water } \\
\text { holding } \\
\text { capacity } \\
(\%)\end{array}$ & $\begin{array}{l}\text { Pore } \\
\text { space } \\
(\%)\end{array}$ & $\begin{array}{l}\text { Sulphate } \\
\text { content } \\
(\mathrm{mg} / \mathrm{l})\end{array}$ & $\begin{array}{c}\text { Chloride } \\
\text { content } \\
(\mathrm{mg} / \mathrm{l})\end{array}$ \\
\hline 0 & 7.20 & 0.027 & 1.61 & 39.00 & 20.21 & 22.7 & 119.5 \\
\hline 5 & 7.43 & 0.032 & 1.72 & 41.12 & 23.75 & 22.0 & 121.1 \\
\hline 10 & 7.65 & 0.037 & 1.84 & 43.46 & 26.81 & 21.2 & 122.7 \\
\hline 15 & 7.86 & 0.042 & 1.95 & 45.75 & 30.02 & 20.7 & 124.6 \\
\hline 20 & 8.07 & 0.048 & 2.12 & 48.36 & 34.55 & 20.5 & 126.4 \\
\hline 25 & 8.24 & 0.052 & 2.32 & 51.12 & 38.87 & 19.9 & 128.1 \\
\hline 30 & 8.49 & 0.057 & 2.55 & 54.20 & 42.30 & 21.7 & 130.3 \\
\hline 40 & 8.72 & 0.064 & 2.77 & 57.25 & 47.16 & 26.1 & 133.5 \\
\hline 50 & 8.95 & 0.071 & 3.05 & 60.45 & 52.29 & 31.0 & 137.2 \\
\hline LSD $(\mathrm{P}<0.05)$ & 0.152 & 0.004 & 0.093 & 2.052 & 2.295 & 0.67 & 1.27 \\
\hline $\operatorname{LSD}(\mathrm{P}<0.01)$ & 0.203 & 0.006 & 0.125 & 2.766 & 3.093 & 0.90 & 1.71 \\
\hline $\begin{array}{c}\text { Treatment } \\
(\%)\end{array}$ & $\begin{array}{c}\text { Nitrogen } \\
\text { (mg/kg) }\end{array}$ & $\begin{array}{l}\text { Phosphorus } \\
\text { (mg/kg) }\end{array}$ & $\begin{array}{c}\text { Potassium } \\
\text { (mg/kg) }\end{array}$ & $\begin{array}{c}\text { Magnesium } \\
\text { (mg/kg) }\end{array}$ & $\begin{array}{c}\text { Zinc } \\
(\mathrm{mg} / \mathrm{kg})\end{array}$ & $\begin{array}{c}\text { Manganese } \\
(\mathrm{mg} / \mathrm{kg})\end{array}$ & $\begin{array}{c}\text { Boron } \\
\text { (mg/kg) }\end{array}$ \\
\hline 0 & 1.5 & 6.6 & 27.5 & 49.5 & 1.27 & 5.12 & 0.31 \\
\hline 5 & - & 6.1 & 26.1 & 48.6 & 1.28 & 5.00 & 0.33 \\
\hline 10 & - & 5.8 & 20.2 & 48.4 & 1.29 & 4.95 & 0.36 \\
\hline 15 & - & 5.6 & 16.5 & 48.2 & 1.30 & 4.91 & 0.39 \\
\hline 20 & - & 5.5 & 13.0 & 48.0 & 1.32 & 4.85 & 0.43 \\
\hline 25 & - & 5.3 & 8.1 & 47.3 & 1.33 & 4.56 & 0.47 \\
\hline 30 & - & 6.2 & 11.0 & 48.6 & 1.40 & 4.87 & 0.54 \\
\hline 40 & - & 8.7 & 22.5 & 50.2 & 1.55 & 5.10 & 0.69 \\
\hline 50 & 3.5 & 11.0 & 32.2 & 52.1 & 1.70 & 5.29 & 0.84 \\
\hline LSD $(\mathrm{P}<0.05)$ & - & 0.11 & 1.31 & 0.89 & 0.026 & 0.092 & 0.032 \\
\hline $\operatorname{LSD}(\mathrm{P}<0.01)$ & - & 0.15 & 1.77 & 1.19 & 0.035 & 0.124 & 0.043 \\
\hline
\end{tabular}


Table 4. Effect of different levels of brick kiln dust as soil application on plant growth and yield of S.tuberosum var. Kufri Alankar (values are mean, $\mathrm{n}=5$ ).

\begin{tabular}{|c|c|c|c|c|c|c|c|c|c|}
\hline \multirow{3}{*}{$\begin{array}{c}\text { Treatment } \\
(\%)\end{array}$} & \multicolumn{6}{|c|}{ Plant growth } & \multicolumn{2}{|c|}{ Yield } & \multirow{3}{*}{$\begin{array}{c}\text { Plant } \\
\text { biomass } \\
\text { (g) }\end{array}$} \\
\hline & \multicolumn{2}{|c|}{ Length (cm ) } & \multicolumn{2}{|c|}{ Fresh wt. (g) } & \multicolumn{2}{|c|}{ Dry wt. (g) } & \multirow{2}{*}{$\begin{array}{c}\text { Tuber } \\
\text { fresh wt. } \\
\text { (g) }\end{array}$} & \multirow{2}{*}{$\begin{array}{l}\text { Tuber } \\
\text { dry wt. } \\
\text { (g) }\end{array}$} & \\
\hline & Root & Shoot & Root & Shoot & Root & Shoot & & & \\
\hline 0 & 20.92 & 29.35 & 5.95 & 34.51 & 0.75 & 4.31 & 104.23 & 17.38 & 22.44 \\
\hline 5 & 23.07 & 32.34 & 6.72 & 39.38 & 0.83 & 4.98 & 116.21 & 20.05 & 25.86 \\
\hline 10 & 25.16 & 35.12 & 7.42 & 45.09 & 0.94 & 5.57 & 129.09 & 22.26 & 28.77 \\
\hline 15 & 27.85 & 38.12 & 8.35 & 50.21 & 1.03 & 6.28 & 142.02 & 23.68 & 30.99 \\
\hline 20 & 31.34 & 41.17 & 9.00 & 55.26 & 1.15 & 6.74 & 151.90 & 24.91 & 32.80 \\
\hline 25 & 34.21 & 44.06 & 9.75 & 60.66 & 1.19 & 7.49 & 165.07 & 26.63 & 35.31 \\
\hline 30 & 29.61 & 37.47 & 8.35 & 54.25 & 1.03 & 6.87 & 149.75 & 24.97 & 32.87 \\
\hline 40 & 21.15 & 31.65 & 6.00 & 35.61 & 0.77 & 4.52 & 118.25 & 20.05 & 25.34 \\
\hline 50 & 17.30 & 24.19 & 4.82 & 28.35 & 0.60 & 3.49 & 82.41 & 14.22 & 18.31 \\
\hline LSD $(\mathrm{P}<0.05)$ & 2.524 & 3.612 & 0.925 & 5.635 & 0.094 & 0.726 & 14.921 & 3.134 & 3.576 \\
\hline LSD $(\mathrm{P}<0.01)$ & 3.402 & 4.869 & 1.247 & 7.596 & 0.127 & 0.979 & 20.114 & 4.225 & 4.821 \\
\hline
\end{tabular}

Table 5. Effect of different levels of brick kiln dust as soil application on photosynthetic pigments and NPK uptake of S.tuberosum var. Kufri Alankar (values are mean, $n=5$ ).

\begin{tabular}{|c|c|c|c|c|c|c|c|}
\hline \multirow{2}{*}{$\begin{array}{c}\text { Treatment } \\
(\%)\end{array}$} & \multicolumn{4}{|c|}{ Photosynthetic pigments (per g fresh weight) } & \multicolumn{3}{|c|}{ NPK amount by plant (dry weight) } \\
\hline & $\begin{array}{c}\text { Chlorophyll a } \\
\text { (mg/g) }\end{array}$ & $\begin{array}{c}\text { Chlorophyll b } \\
\text { (mg/g) }\end{array}$ & $\begin{array}{c}\text { Total } \\
\text { chlorophyll } \\
(\mathrm{mg} / \mathrm{g})\end{array}$ & $\begin{array}{l}\text { Carotenoids } \\
(\mathrm{mg} / \mathrm{g})\end{array}$ & $\begin{array}{c}\text { Nitrogen } \\
\text { (mg/plant) }\end{array}$ & $\begin{array}{c}\text { Phosphorus } \\
\text { (mg/plant) }\end{array}$ & $\begin{array}{l}\text { Potassium } \\
\text { (mg/plant) }\end{array}$ \\
\hline 0 & 0.79 & 0.37 & 1.16 & 0.0042 & 280 & 15.7 & 127 \\
\hline 5 & 0.83 & 0.41 & 1.24 & 0.0044 & 278 & 18.0 & 130 \\
\hline 10 & 0.88 & 0.45 & 1.33 & 0.0047 & 272 & 20.1 & 146 \\
\hline 15 & 0.91 & 0.48 & 1.39 & 0.0049 & 266 & 21.6 & 154 \\
\hline 20 & 0.95 & 0.57 & 1.52 & 0.0052 & 263 & 22.8 & 163 \\
\hline 25 & 1.03 & 0.61 & 1.64 & 0.0055 & 260 & 24.6 & 175 \\
\hline 30 & 0.96 & 0.53 & 1.49 & 0.0050 & 254 & 22.9 & 164 \\
\hline 40 & 0.83 & 0.40 & 1.23 & 0.0044 & 245 & 17.5 & 125 \\
\hline 50 & 0.75 & 0.26 & 1.01 & 0.0041 & 227 & 12.7 & 91 \\
\hline LSD $(\mathrm{P}<0.05)$ & 0.064 & 0.041 & 0.110 & 0.0003 & 5.4 & 2.12 & 4.5 \\
\hline $\operatorname{LSD}(\mathrm{P}<0.01)$ & 0.086 & 0.055 & 0.148 & 0.0004 & 7.3 & 2.86 & 6.1 \\
\hline
\end{tabular}

Table 6. Effect of different levels of brick kiln dust as soil application on protein and carbohydrate contents of $S$. tuberosum var. Kufri Alankar (values are mean, $\mathrm{n}=5$ ).

\begin{tabular}{ccccccc}
\hline $\begin{array}{c}\text { Treatment } \\
(\boldsymbol{\%})\end{array}$ & $\begin{array}{c}\text { Soluble } \\
\text { protein } \\
(\boldsymbol{\%})\end{array}$ & $\begin{array}{c}\text { Protein content } \\
\text { Insoluble } \\
\text { protein } \\
(\boldsymbol{\%})\end{array}$ & $\begin{array}{c}\text { Total } \\
\text { protein } \\
(\boldsymbol{\%})\end{array}$ & $\begin{array}{c}\text { Soluble } \\
\text { carbohydrate } \\
(\boldsymbol{\%})\end{array}$ & $\begin{array}{c}\text { Carbohydrate content } \\
\text { Insoluble } \\
\text { carbohydrate } \\
(\boldsymbol{\%})\end{array}$ & $\begin{array}{c}\text { Total } \\
\text { carbohydrate } \\
(\boldsymbol{\%})\end{array}$ \\
\hline 0 & 2.57 & 5.05 & 7.62 & 7.15 & 10.37 & 17.52 \\
5 & 2.31 & 4.34 & 6.65 & 7.41 & 10.61 & 18.02 \\
10 & 2.01 & 3.86 & 5.87 & 7.63 & 10.94 & 18.57 \\
15 & 1.85 & 3.46 & 5.31 & 8.09 & 11.23 & 19.32 \\
20 & 1.73 & 3.21 & 4.94 & 8.47 & 11.51 & 19.98 \\
25 & 1.62 & 2.95 & 4.57 & 8.81 & 11.85 & 20.66 \\
30 & 1.67 & 2.98 & 4.65 & 8.00 & 11.33 & 19.33 \\
40 & 1.72 & 3.22 & 4.94 & 7.37 & 10.62 & 17.99 \\
50 & 1.86 & 3.46 & 5.32 & 6.91 & 9.89 & 16.80 \\
LSD (P<0.05) & 0.351 & 0.752 & 1.022 & 0.352 & 0.424 & 0.753 \\
LSD (P<0.01) & 0.473 & 1.013 & 1.377 & 0.475 & 0.572 & 1.015 \\
\hline
\end{tabular}




\section{DISCUSSION}

Brick kiln dust is a second major particulate air pollutant after fly ash in India (Upadhyay 2004). It contains mixture of ashes (coal + wood) and dust particles (soil + sand). The $\mathrm{pH}, \mathrm{EC}, \mathrm{CEC}$, WHC and pore space were increased gradually with respect to brick kiln dust level in soil. Because the elements present in ashes enriched the soils, and dust particles increased the pore spaces, as dust contains mostly sand particles, which are used during the preparation of raw bricks and are detached during combustion. Upadhyay (2004) has also observed the similar results in these parameters of brick kiln dust. The increment in the elemental composition, due to the ashes of coal and wood has also been observed by Upadhyay (2004) and Upadhyay et al. (2008).

After harvesting of $S$. tuberosum, all the physico-chemical properties of brick kiln dust amended soil were less in respective parameters as compared to before planting, except $\mathrm{pH}$, sulphate, chloride and magnesium because their concentration were greater than before planting. The increment in these parameters was due to addition of water (irrigation), which contains all theses elements. Concentration of nitrogen was nil in all the levels of amended soil, except at $50 \%$ level and in control. The reductions in the concentrations of the elements were due to the absorption of these elements by potato. When concentrations of elements in the available form were calculated, it was observed that the sum of amount before planting and amount present in water were equal to the sum of amount after harvesting + amount taken up by plants. These results also collaborate with Upadhyay (2004).

In the soil application of brick kiln dust, the length, fresh and dry weights of root and shoot, fresh and dry weights of tubers, plant biomass, photosynthetic pigments, $\mathrm{P}$ and $\mathrm{K}$ concentrations of plants and carbohydrate contents of potato tubers were increased upto $40 \%$ brick kiln dust levels, however, all parameters were highest at $25 \%$ level. While, Raghav and Khan (2002) observed that $15 \%$ level of brick kiln dust was best for tomato plant. Upadhyay (2004) reported that the growth of Brassica juncea and Linum usitatissimum were best at $45 \%$ level of brick kiln dust. These studies indicate that different plant species require the macro and micro nutrients at a particular limit, beyond that the elements become harmful. This may be due to their different genetic make-up. Addition of brick kiln dust increased the physico-chemical properties, which had favourable effect on plants. Elseewi et al. (1981) suggested that EC is positively correlated with $\mathrm{pH}$ that affects the concentration of soluble cations and anions, which are available to plants at certain level. The physical and chemical properties of brick kiln dust at $25 \%$ level were found best for increasing the plant growth, yield, photosynthetic pigments, biomass and carbohydrate contents of potato in the present study.

After 25\% level, the above parameters declined gradually with respect to levels. This might be due to more absorption of elements, which acted, as phytotoxic in subsequent levels. Gradual decline in plant growth, yield and other parameters was also attributed probably to increased alkalinity and salinity, caused by higher levels of sulphate and chloride in amended soils. Possibly higher amount of Mn, Zn and B became phytotoxic to potato crop. Similar trends in reduction at higher levels have also been observed in B. juncea and L. usitatissimum by Upadhyay (2004). Brick kiln dust also caused deficiency of nitrogen in soils. Deficiency of nitrogen at higher level of dust application might have adversely affected the protein content, because it is a component of protein synthesis (Devlin and Witham 2000). 


\section{REFERENCES}

Devlin, R.M. and F.H. Witham. 2000. Plant Physiology. CBS Publishers and Distributors, New Delhi, 577 pp.

Elseewi, A.A., S.R. Grimm, A.L. Page and I.R. Straughan. 1981. Boron enrichment of plants and soils treated with coal ash. J. Plant Nutr. 3:409-427.

Gupta, P.K. 2002. Methods in Environmental Analysis Water, Soil and Air. Published by Updesh Purohit for Agrobios, Jodhpur, India, 438 pp.

Heck, W.W., R.H. Daines and I.J. Hindawi. 1970. Other phytotoxic pollutants. In: Recognition of Air Pollution Injury to Vegetation: A Pictorial Atlas. (eds.) Jacobson, J.S. and A.C. Hill. Air Pollution Control Association, Pittsburgh, Pennsylvania, USA.

Khan, A.A., S. Kausar and I. Diva. 2006. Study of plant growth and yield of underground stem crops in fly ash amended soil. Asian J. Water, Environ. and Pollut. 4(2):87-91.

Khan, M.R. 1989. Studies on root-knot nematodes in relation to environmental pollution on vegetable crops. Ph.D. Thesis, Aligarh Muslim University, Aligarh, India.

Khan, S.T.B. and J. Singh. 1996. Effect of fly ash on physico-chemical properties and nutrient status of soil. Ind. J. Environ. Health 38:4146.

Lowery, O.H., N.J. Rosebrough, A.L. Farr and R.J. Randal. 1951. Protein measurement with folin phenol reagent. J. Bio. Chem. 193:265-275.

MacLachlan, S. and S. Zalik. 1963. Plastid structure, chlorophyll concentration and free amino acid composition of chlorophyll mutant of barley. Can. J. Bot. 41:1053-1062.
Mishra, L.C. and K.N. Shukla. 1986. Effect of fly ash deposition on growth, metabolism and dry matter production of maize and soybean. Environ. Pollut. 42:1-13.

Olsen, S.R., C.V. Cole, F.S. Watanabe and L.A. Dean. 1956. Estimation of available phosphorus in soils by extraction with sodium bicarbonate. Circ. U.S. Dept. Agri. 939:1-19.

Raghav, D. and A.A. Khan. 2002. Impact of industrial particulate pollutants applied to soil on growth and yield of tomato. Thai J. Agric. Sci. 35:187-194.

Rizvi, R. and A.A. Khan. 2009. Response of eggplant (Solanum melongena L.) to fly ash and brick kiln dust amended soil. Biol. and Medic. 1(2):20-24.

Subbiah, B.V. and C.L. Asija. 1956. Rapid producer for estimation of available nitrogen in soil. Curr. Sci. 25:259-260.

Upadhyay, E. 2004. Impact of particulate air pollutants on Brassica juncea L. and Linum ustiatissimum L. Ph.D. Thesis, Aligarh Muslim University, Aligarh, India.

Upadhyay, E., A.A. Khan, S. Kausar and D. Tomar. 2008. Physico-chemical properties of fly ash amended soil before sowing and after harvesting of mustard and its impact on plant growth. In: Proc. All India Seminar in Environ. Sci. and Tech. Feb.15-16, 2008. AMU, Aligarh, pp. 279-283.

Wong, M.H. and J.W.C. Wong. 1989. Germination and seedling growth of vegetable crops in fly ash amended soils. Agr. Ecol. Environ. 26:2335 .

Yih, R.Y.C. 1965. Carbohydrate and protein contents of boron deficient tomato and root tips in relation to anatomy and growth. Plant Physiol. 40:312-315. 